\title{
Validation of the Brazilian version of Primary Care Assessment Tool (PCAT) for Oral Health - PCATool Brazil Oral Health for Professionals
}

\author{
Validação da versão brasileira do Primary Care Assessment Tool \\ (PCAT) para Saúde Bucal - PCATool Brasil Saúde Bucal \\ para Profissionais
}

Otávio Pereira D’Avila (http://orcid.org/0000-0003-1852-7858) ${ }^{1}$

Erno Harzheim (http://orcid.org/0000-0002-8919-7916) ${ }^{2}$

Lisiane Hauser (http://orcid.org/0000-0003-3324-5533) ${ }^{2}$

Luiz Felipe Pinto (http://orcid.org/0000-0002-9888-606X) 2,3

Eduardo Dickie de Castilhos (https://orcid.org/0000-0002-7072-6558) ${ }^{1}$

Fernando Neves Hugo (http://orcid.org/0000-0003-2222-7719) ${ }^{4}$

${ }^{1}$ Programa de PósGraduação em Odontologia, Universidade Federal de Pelotas. R. Gonçalves Chaves 457, Centro. 96015560 Pelotas RS Brasil. otaviopereiradavila@ gmail.com

${ }^{2}$ Programa de PósGraduação em

Epidemiologia, Faculdade de Medicina, Universidade Federal do Rio Grande do Sul (UFRGS). Porto Alegre

RS Brasil.

${ }^{3}$ Faculdade de Medicina,

Universidade Federal do Rio

de Janeiro. Rio de Janeiro

RJ Brasil.

${ }^{4}$ Programa de Pós-

Graduação em Odontologia,

UFRGS. Porto Alegre RS

Brasil.

\begin{abstract}
This study verified the internal consistency and reliability of an instrument to evaluate dental services in Primary Health Care (PHC). In order to verify the factor validity, a factor analysis with principal component extraction and varimax orthogonal rotation method was used. Factors with three or more items with factor loadings greater than 0,35 were selected. This instrument's reliability was verified using internal consistency (total item correlation $>0,30$ and Cronbach alpha $=$ or $>0,70)) .562$ dentists participated in the study. In the factor analysis, ten factors were kept, which explain 40,95\% of the total variation. Regarding the internal consistency, only 3 items presented insufficient correlation. Also on internal consistency, using Cronbach's alpha, the following values of the coefficients were identified: Access (0.55), Continuity (0,74), Care Coordination $(0,55)$, Coordination - Information System (0.21), Comprehensiveness of Services Available $(0,91)$, Comprehensiveness of Services Provided $(0,79)$, Family Orientation (0.66), Community Orientation $(0,87)$, Cultural Competence $(0,81)$. For the success ratio of the scale, all results were higher than $88 \%$, less the "Information Systems" component (21\%).
\end{abstract}

Key words Primary Health Care, Oral Health, Health Services Evaluation, Monitoring
Resumo Este estudo verificou a consistência interna e a confiabilidade de um instrumento para avaliar os serviços odontológicos na Atenção Primária à Saúde (APS). Para verificar a validade dos fatores, foi utilizada uma análise fatorial com extração de componentes principais e método de rotação ortogonal varimax. Foram selecionados fatores com três ou mais itens com cargas fatoriais maiores que 0,35. A confiabilidade deste instrumento foi verificada usando consistência interna (correlação total de itens $>0,30$ e alfa de Cronbach $=o u>0,70) .562$ dentistas participaram do estudo. $\mathrm{Na}$ análise fatorial, foram mantidos dez fatores, o que explica 40,95\% da variação total. Quanto à consistência interna, apenas 3 itens apresentaram correlação insuficiente. Ainda na consistência interna, utilizando o alfa de Cronbach, foram identificados os seguintes valores dos coeficientes: Acesso (0,55), Continuidade (0,74), Coordenação de Atenção $(0,55)$, Coordenação - Sistema de Informação $(0,21)$, Abrangência dos Serviços Disponíveis (0,91), Abrangência dos serviços prestados $(0,79)$, Orientação familiar $(0,66)$, Orientação comunitária $(0,87)$, Competência cultural $(0,81)$. Para a taxa de sucesso da escala, todos os resultados foram superiores a $88 \%$, menos o componente "Sistemas de Informação" (21\%).

Palavras-chave Atenção Primária à Saúde, Saúde Bucal, Avaliação de Serviços de Saúde, Monitoramento 


\section{Introduction}

Primary Health Care (PHC) has established it self as one of the most equitable and efficient ways of organizing a health system ${ }^{1}$. It can be defined by its essential attributes: 1) first-contact accessibility, 2) continuity, 3) comprehensiveness, 4) care coordination; and derived attributes, 5) family and community-centered attention, and 6) cultural competence ${ }^{2-4}$.

In Brazil, the Family Health Strategy (FHS) is an effort conducted by the Ministry of Health $(\mathrm{MOH})$ to develop a public health policy able to establish a sturdy PHC model. In April 2003, 19,068 FHS teams, or 62,339,523 million of individuals, were covered by the FHS. In April 2020, 44,716 FHS teams or 137,360,577 million of individuals, started to be covered ${ }^{5}$. Oral health in Brazil started to be supported by the PHC model in 2003, with the launch of the National Oral Health Program, also known as Brasil Sorridente. Initially, the program expanded the coverage of oral health services in PHC, with the objective of expanding access and establishing guidelines to reorient oral health services, taking as a central axis the offer of services and actions associated with the attributes of $\mathrm{PHC}^{6}$.

Different conceptual models and instruments have been unfurled in recent years to evaluate the quality of health care, some of which include the PHC2 attributes ${ }^{2,7,8}$. The Primary Care Assessment (PCATool) was one of those, a set of instruments capable of measuring the presence and extension of PHC attributes, developed by Starfield and collaborators at The Johns Hopkins Populations Care Policy Center for the Underserved Populations, in Baltimore (USA) ${ }^{2,9-11}$.

PCATool is an instrument able to assess the quality of primary care provided, based on the measurement of the extent of PHC attributes, producing a score for each attribute, an essential score and an overall score on the quality of care. It allows an opportunity to comparatively assess the degree of success of services when it comes to achieving excellence in PHC practice ${ }^{11,12}$. In Brazil, the versions for adult users ${ }^{13}$, children ${ }^{14}$, health professionals ${ }^{15,16}$ and also oral health version from the perspective of the adult user have already been translated, adapted and validated ${ }^{17}$. It is one of the most frequently used PHC assessment instruments in the country ${ }^{18}$. It has recently been cited as one of the instruments that will compose the National Home-based Health Research that will enable the collection of relevant information about the health of the pop- ulation and the capacity of the Unified Health System (SUS), focusing on Primary Health Care (PHC). It encompasses the National Continuous Household Sample Survey (Continuous PNAD), the National Demographic and Health Survey (PNDS), and the Health-Medical Assistance Survey (AMS) ${ }^{19}$. In addition, PCATool Brazil started to compose an extension of payment for performance of the new financing model for APS do Brazil $^{20}$ and a new PCATool Brazil manual was released by the Ministry of Health, with guidance on its use in estimates ${ }^{21}$.

Within the scope of evaluation of oral health services in PHC from the user's perspective, in addition to the PCATool Brazil - Oral Health Adult User, there is also the QASSAB instrument (Questionnaire for Evaluation of Quality of Oral Health Services) and the instrument of External Evaluation of the National Program for Improving Access and Quality of Basic Care (PMAQ $A B)^{22}$. The evaluation from the user's perspective is important because they are the target audience of the services and the opportunity to know their satisfaction in terms of structures, processes and results presented by the health service that they use is important information for improving the actions and services provided.

On the other hand, the assessment of health services encompasses both those who use and those who provide and produce the services. Therefore, it is necessary to acknowledge that users and professionals have different and complementary positions within the evaluative context, and both are important for the analysis of the services researched. The PMAQ-AB presented an evaluation instrument from the perspective of the professional, whose main objective is to provide management subsidies. Nevertheless, no instruments were found to assess oral health services in PHC from a professional perspective that had validated its psychometric characteristics.

PCATool is a set of instruments developed from PHC's sturdy theoretical framework ${ }^{2,9,10}$ and has been used in different countries, not only for academic research purposes but also for decision making of managers ${ }^{23}$. Given the breakthroughs registered by $\mathrm{PHC}$ and the expansion of oral health in the FHS in Brazil, it is relevant, at this point, to assess the results achieved in relation to the organization and provision of oral health services in the health care network. Therefore, it is essential to provide instruments for assessing oral health services in PHC that allow for international comparisons, capable of reflecting instruments that assess PHC attributes from the 


\section{Outlining}

Cross-sectional validation study of PCATool Brazil Oral Health - Professional.

\section{Sample}

This instrument has presented 98 evaluation items after its adaptation. In order to meet the study's objectives, data were collected using a convenience sample composed of 562 participants, complying with the minimum threshold of 5 interviews for each item of the instrument necessary for the application of factor analysis, a methodology used to assess the validity of the instrument ${ }^{23}$. The participants were dental surgeons (DS) of the Primary Health Care (PHC) of municipalities in the State of Rio Grande do Sul (Alvorada, Anta Gorda, Arroio do Meio, Arvorezinha, Bom Retiro do Sul, Canudos do Vale, Capitão, Colinas, Coqueiro Baixo, Cruzeiro do Sul, Doutor Ricardo, Encantado, Estrela, Fazenda Vilanova, Forquetinha, Gravataí, Ilópolis, Imigrante, Lajeado, Marques de Souza, Muçum, Nova Bréscia, Novo Hamburgo, Paverama, Pelotas, Porto Alegre, Poço das Antas, Pouso Novo, Progresso, Putinga, Relvado, Roca Sales, Santa Clara do Sul, Sapucaia do Sul, Sério, Tabaí, Taquari, Teutônia, Travesseiro, Venâncio Aires, Vespasiano Corrêa, Viamão and Westfália) and from the municipality of Rio de Janeiro.

All dental surgeons who were working in the same Basic Health Unit for at least six months before the date of the interview were included in the study.

\section{Adaptation}

PCATool Brazil Oral Health - Professional is a "mirror" questionnaire for PCATool Brasil - Professional ${ }^{16}$ and PCATool Brasil Oral Health - Adult User ${ }^{17}$. Therefore, to adapt the professional version to an oral health approach, the instrument was adapted from PCATool Brazil Oral Health - Adult User. The adaptation consisted of replacing the expression "your health service" with "your oral health service", except for the dimension "Comprehensiveness". For this dimension in specific, the instrument PCATool Brasil Oral Health - Adult User ${ }^{17}$ was used as a mirror.

A previous validation study identified that among, the seven attributes that make up the questionnaire, only the comprehensiveness dimension (services available/services provided) did not properly assess this dimension in relation to oral health. To develop the "comprehensiveness" dimension, this study used the Delphi Technique to build a consensus among experts (university professors and dentists with extensive experience in PHC) for the instrument PCATool Brasil Oral Health - Adult User ${ }^{24}$. Therefore, the comprehensiveness dimension, developed and validated for oral health services of PHC in Brazil, was used for the instrument PCATool Brazil Oral Health - Professional.

\section{PCATool Brazil Oral Health - Professional}

The PCATool Brazil Oral Health - Professional version instrument encompasses 98 items distributed among the essential attributes - access, continuity, comprehensiveness and coordination - and their derivatives - family and community orientation and cultural competence. It was originally developed to assess the presence and extent of PHC attributes in health services. The item's responses are presented in Likert-type scales, with values ranging from $1=$ "certainly not" to $4=$ "certainly yes", with the additional option $9=$ “don't know/can't remember". From the answers, it is possible to calculate a score for each PHC attribute and also an essential score and an overall score. At least $50 \%$ of valid answers ( $4=$ "certainly yes", 3 = "probably yes", 2= "probably not" or $1=$ "certainly not") is a condition to calculate the score. If the condition is met, the code responses 9= "I don't know/can't remember" should be transformed to code $2=$ "probably not" according to guidelines in the Instrument $\mathrm{Manual}^{21}$, as statistically demonstrated by Hauser ${ }^{25}$.

The essential score is obtained by averaging the scores of the essential attributes - first contact, continuity, comprehensiveness and coordination. In addition to these, the overall score includes the derived attributes - family orientation, community orientation and cultural competence. The score values are turned into a scale ranging from 0 to 10 . A value equal to or greater than 6,6 is considered a high score. 


\section{Data collection}

The professionals were identified, contacted and invited to participate in the study by telephone. The contacts were passed on by the Municipal Health Departments. Prior consent was requested from the departments in order to carry out the research and provide the contact data of the Basic Health Units (BHU). The professionals who did not agree to participate were regarded as refusals.

The research instrument was used during the oral health coordination meetings of the municipalities. Also, information was collected on sex, postgraduate education and the BHU model in which the DSs worked. A researcher, previously trained, presented the research project and each item of the instrument PCATool Brasil SB - Professional. The doubts were clarified and the instrument was handed to the professionals for them to answer. The interviews were conducted between March 2014 and December 2015 and the researcher stayed in the room to address any doubts that might arise. The average time to complete the research instrument was 25 minutes.

\section{Statistical Analysis}

In order to verify the factor validity, a factor analysis with principal component extraction and varimax orthogonal rotation method was used. Factors with three or more items with factor loadings greater than $0,35^{26}$ were selected.

This instrument's reliability was verified using the internal consistency, the success ratio of the scale and the stability over time. Regarding the assessment of internal consistency, the item-total correlation was used, taking into consideration appropriate items with a value higher than $0,30^{26}$ and the Cronbach's alpha coefficient ideally equal or higher than $0,70^{26}$. For the scale's success ratio, it was verified the quotient between the number of times that correlations between the items of an attribute were higher than the correlations of each of these items with other attributes and the total number of correlations found in that attribute. High values of that measure suggest greater attribute discrimination.

The instrument's stability over time was assessed by comparing the scores of PHC attributes in ten-day intervals between test and retest. We randomly selected $10 \%$ of the sample for a new phone interview.

Wilcoxon's statistical test was applied to two paired samples. All analyses were conducted us- ing the SAS (Statistical Analysis Software) version 9.4 and the 5\% significance level was considered.

\section{Ethical Aspects}

The research project "Evaluation of Oral Health Services in Primary Health Care - A conceptual, psychometric, exploratory and structural analysis" was submitted to and approved by the Research Ethics Committees of the Municipal Administration of Porto Alegre and the Federal University of Rio Grande do Sul. The interviews with service professionals were carried out after reading and signing the Informed Consent Form (ICF), in tune with the ethical precepts established in the Declaration of Helsinki.

\section{Results}

The sample consisted of 562 dental surgeons interviewed. During the data collection period, there was an attempt to contact 613 DSs. Among them, 24 were not found, 15 refused to participate in the survey and 12 had less than six months of experience in the current BHU. Therefore, the loss of the original sample was $9 \%$.

Of the interviewees, $76,7 \%$ were women, $81,2 \%$ had some specialty and for, $44,29 \%$, the declared specialty was family health/public health/collective health. The family health strategy was the PHC model declared by $81,5 \%$ of professionals.

\section{Factorial Analysis}

The exploratory factor analysis kept 10 factors that explain $40,95 \%$ of the total variation. These factors represented, in a more homogeneous manner, the attributes that allow measuring the presence and extension of PHC and its essential and derived attributes. Regarding the distribution of the items in the factors, the First-Contact Access - Accessibility was captured by factor 5 . Continuity was kept in factor 4 (Table $1)$. The care coordination was captured by factor 8 (Table 2).

The Comprehensiveness of services available presented items in factor 1 , and the same is true for the Comprehensiveness of services provided (Table 3). The attributes derived from family orientation, community orientation and cultural competence were captured by factors 3, 2 and 2, respectively (Table 4 ). The coordination of Information Systems was the only dimension that 
Table 1. Factorial loadings for factor validity and item-total correlation of attributes First-contact access accessibility and continuity.

\begin{tabular}{|c|c|c|c|}
\hline \multicolumn{2}{|r|}{ Attributes of Primary Health Care } & $\begin{array}{l}\text { Item-total } \\
\text { correlation }\end{array}$ & $\begin{array}{c}\text { Factorial } \\
\text { Loading }\end{array}$ \\
\hline \multicolumn{4}{|c|}{ First Contact Access - Accessibility } \\
\hline A1 & Is your oral health service open on Saturdays or Sundays? & - & $-0,12^{\star}$ \\
\hline A2 & $\begin{array}{l}\text { Is your oral health service open at least a few working day evenings until 8:00 } \\
\text { p.m.? }\end{array}$ & - & $0,00^{*}$ \\
\hline A3 & $\begin{array}{l}\text { When your oral health service is open, and any of your patients has an issue } \\
\text { with their mouth or teeth, does someone at the service see that person on the } \\
\text { same day? }\end{array}$ & 0,20 & $0,27^{* *}$ \\
\hline A4 & $\begin{array}{l}\text { When your oral health service is open, do patients get quick guidance over the } \\
\text { phone when deemed necessary? }\end{array}$ & 0,31 & 0,58 \\
\hline A5 & $\begin{array}{l}\text { When your oral health service is closed, is there a phone number that patients } \\
\text { can call when they have an issue with their mouth or teeth? }\end{array}$ & 0,37 & 0,37 \\
\hline A6 & $\begin{array}{l}\text { When your oral health service is closed on Saturdays and Sundays, and some } \\
\text { of your patients have a mouth or tooth issue, does someone at your service see } \\
\text { that person on the same day? }\end{array}$ & 0,33 & 0,44 \\
\hline A7 & $\begin{array}{l}\text { When your oral health service is closed and any of your patients have a mouth } \\
\text { or teeth issue during the night, does anyone at your service see that person on } \\
\text { that same night? }\end{array}$ & 0,27 & 0,75 \\
\hline A8 & $\begin{array}{l}\text { Is it easy for a patient to schedule a routine check-up appointment at your } \\
\text { oral health service? }\end{array}$ & 0,24 & 0,71 \\
\hline A9 & $\begin{array}{l}\text { On average, do your patients have to wait more than } 30 \text { minutes to be seen by } \\
\text { the dentist (already discounting screening or admission processes)? }\end{array}$ & 0,19 & 0,40 \\
\hline B1 & In your health service, are patients always seen by the same dentist? & 0,17 & 0,47 \\
\hline B2 & Can you understand the questions asked by your patients? & 0,31 & 0,45 \\
\hline B3 & Do you think your patients understand what you are saying or asking? & 0,26 & 0,37 \\
\hline B4 & $\begin{array}{l}\text { If your patients have a question or concern, can they call and talk to the } \\
\text { dentist who knows them best? }\end{array}$ & 0,24 & 0,58 \\
\hline B5 & $\begin{array}{l}\text { Do you give your patients enough time to talk about their concerns or } \\
\text { problems? }\end{array}$ & 0,37 & 0,51 \\
\hline B6 & $\begin{array}{l}\text { Do you think your patients are comfortable telling you about their concerns } \\
\text { and problems? }\end{array}$ & 0,39 & 0,52 \\
\hline B7 & Do you think you know the patients in your health service "very well"? & 0,52 & 0,66 \\
\hline B8 & Do you know who lives with each of your patients? & 0,52 & 0,5 \\
\hline B9 & $\begin{array}{l}\text { Do you understand which problems are most important to the patients you } \\
\text { care for? }\end{array}$ & 0,35 & 0,42 \\
\hline $\mathrm{B} 10$ & Do you know the complete oral health history of each patient? & 0,44 & 0,40 \\
\hline B11 & Do you know each patient's job or work? & 0,44 & 0,48 \\
\hline B12 & $\begin{array}{l}\text { Would you know if your patients did not get the prescribed medications or } \\
\text { struggle to pay for them? }\end{array}$ & 0,33 & 0,32 \\
\hline B13 & Do you know all the medications your patients are taking? & 0,29 & 0,35 \\
\hline
\end{tabular}

${ }^{*}$ Items removed from the final instrument, ${ }^{* *}$ Items conceptually included in the final instrument.

Source: Elaborated by the authors.

did not present a factor load greater than 0,35 in the items assessed (Table 2). This dimension was kept due to its conceptual importance.

The instrument PCATool Brazil Oral Health Professional adapted for primary health care services in Brazil was initially formed by 98 items. After validation, 85 items were kept in the final instrument.

\section{Reliability}

Regarding the internal consistency, taking into account the item-total correlation, for access (Table 1), items A3 (When the patient has a mouth issue, does someone in the service see that person the same day?), A7 (When the patient has a mouth issue at night, does someone at the service 
Table 2. Factorial loadings for factor validity and item-total correlation of attributes Coordination - Integration of Care and Coordination - Information Systems.

\begin{tabular}{|c|c|c|c|}
\hline & Attributes of Primary Health Care & $\begin{array}{l}\text { Item-total } \\
\text { correlation }\end{array}$ & $\begin{array}{l}\text { Factorial } \\
\text { Loading }\end{array}$ \\
\hline \multicolumn{4}{|c|}{ Coordination - Care Integration } \\
\hline $\mathrm{C} 1$ & $\begin{array}{l}\text { Does your oral health service communicate or deliver every laboratory test } \\
\text { results to your patients? }\end{array}$ & - & $0,21^{*}$ \\
\hline $\mathrm{C} 2$ & $\begin{array}{l}\text { Do you know all the appointments your patients make with specialists or } \\
\text { specialized services? }\end{array}$ & 0,22 & 0,38 \\
\hline C3 & $\begin{array}{l}\text { When your patients need a referral, do you discuss with your patient different } \\
\text { services where they could be checked? }\end{array}$ & - & $0,26^{*}$ \\
\hline $\mathrm{C} 4$ & Does anyone in your health service help you make an appointment for a referral? & 0,31 & 0,46 \\
\hline C5 & $\begin{array}{l}\text { When your patients are referred, do you give them any written information to } \\
\text { take to the specialist or specialized service? }\end{array}$ & 0,26 & 0,45 \\
\hline C6 & $\begin{array}{l}\text { Do you get from the specialist or specialist service useful information about the } \\
\text { referred patient? }\end{array}$ & 0,38 & 0,50 \\
\hline C7 & $\begin{array}{l}\text { After the appointment with the specialist or specialized service, do you talk to } \\
\text { your patient about the results of the appointment? }\end{array}$ & 0,33 & 0,51 \\
\hline \multicolumn{4}{|c|}{ Coordination - Information Systems } \\
\hline D1 & $\begin{array}{l}\text { Do you ask your patients to bring their past oral health records or patient charts? } \\
\text { (emergency records with a dentist, teeth x-rays) }\end{array}$ & 0,29 & $-0,10^{\star *}$ \\
\hline $\mathrm{D} 2$ & Would you allow your patients to check your medical records if they wanted to? & 0,14 & $0,21^{* *}$ \\
\hline D3 & Are your patient records always available when you see them? & 0,08 & $0,31^{\star *}$ \\
\hline
\end{tabular}

${ }^{\star}$ Items removed from the final instrument, ${ }^{*}$ Items conceptually included in the final instrument.

Source: Elaborated by the authors.

see that person the same day?) and $\mathrm{A} 8$ (Is it easy to make an appointment at your oral health service?) presented moderate correlation values. Item A9 (On average, do your patients have to wait more than 30 minutes to be seen?) presented insufficient item-total correlation values. For continuity ( $\mathrm{Ta}$ ble 1), B3 (Do you think your patients understand what you say or ask?) and B4 (Can your patients call and talk to the dentist who knows them best?) presented moderate correlation values. Item B1 (Are patients always seen by the same dentist at your health service?) presented insufficient item-total correlation values. Regarding care coordination (Table 2), items C4 (Does someone in the service help the patient make a referral appointment?) and C5 (When your patients are referred, do you provide written information to inform the specialist or service?) presented moderate correlation values. In Cultural Competence (Table 4), only item I1 (Do you make home visits?) presented a value regarded as insufficient.

Also on internal consistency, using Cronbach's alpha, the following coefficient values were observed (Table 5): Access (0,55), Continuity $(0,74)$, Care Coordination $(0,55)$, Coordination - Information System (0,21), Comprehensiveness of Services Available (0,91), Comprehensiveness of Services Provided (0.79), Family Orientation $(0,66)$, Community Orientation $(0,87)$, Cultural Competence $(0,81)$.

For the scale's success ratio (SSR), all results were higher than $88 \%$, except for the "Information Systems" component (SSR=21\%), (Table 5).

\section{Discussion}

This study adapted and assessed the validity and reliability of the PCATool Brazil Oral Health Professional version in the public PHC services, indicating that the instrument is valid and reliable for the measurement of the quality of PHC health services based on the experience of the interviewed Dental Surgeons. In the factor analysis, the ten-factor model was capable of capturing the four essential attributes and three attributes derived from the PHC, according to the Starfield proposition $^{1}$, therefore identifying the construct's multidimensional nature. This phenomenon is also found in the adult user, child user and health professional versions of PCATool validated in Brazill $^{13,14,16}$. 
Table 3. Factorial Loadings for factor validity and item-total correlation of attributes Comprehensiveness - Services Available and Comprehensiveness - Services Provided.

\begin{tabular}{|c|c|c|c|}
\hline \multicolumn{2}{|r|}{ Attributes of Primary Health Care } & $\begin{array}{l}\text { Item-total } \\
\text { correlation }\end{array}$ & $\begin{array}{l}\text { Factorial } \\
\text { Loading }\end{array}$ \\
\hline \multicolumn{4}{|c|}{ Comprehensiveness - Available Services } \\
\hline E1 & Preventive examination of the mouth (oral cancer) & - & $0,26^{*}$ \\
\hline E2 & Teeth filling or obturation & 0,42 & 0,53 \\
\hline E3 & Exodontia or tooth extraction & 0,47 & 0,51 \\
\hline $\mathrm{E} 4$ & Application of fluoride on the teeth and guidance on its use & - & $0,28^{*}$ \\
\hline E5 & Gum disease treatment & 0,40 & 0,43 \\
\hline E6 & Emergency care in cases of pain, bleeding or trauma/accident/impact & 0,35 & 0,37 \\
\hline E7 & Treatment and guidance for people with bad breath & 0,49 & 0,54 \\
\hline E8 & $\begin{array}{l}\text { Care provided to the pregnant woman by the dentist/antenatal dental } \\
\text { consultation }\end{array}$ & 0,41 & 0,46 \\
\hline E9 & Treatment and guidance for canker sores & 0,46 & 0,56 \\
\hline E10 & Guidance on how to take care of dental prostheses & 0,58 & 0,64 \\
\hline E11 & $\begin{array}{l}\text { Guidance for the treatment of symptoms in cases of temporomandibular joint } \\
\text { pain }\end{array}$ & 0,51 & 0,51 \\
\hline E12 & Nutrition and diet advice & 0,46 & 0,37 \\
\hline E13 & Treatment and guidance in case of pericoronitis & 0,51 & 0,58 \\
\hline E14 & Oral health treatment and guidelines for disabled patients & 0,43 & 0,37 \\
\hline E15 & Counseling on how to stop smoking & 0,46 & 0,35 \\
\hline E16 & $\begin{array}{l}\text { Oral health treatment and guidance for patients who are bedridden or unable to } \\
\text { leave their homes }\end{array}$ & - & $0,24^{*}$ \\
\hline E17 & Guidance about issues that may occur with mouth piercings & 0,47 & 0,39 \\
\hline E18 & Orientation and referral of people who mouth breathe for medical treatment & 0,57 & 0,46 \\
\hline E19 & Guidance on herpes simplex & 0,65 & 0,68 \\
\hline $\mathrm{E} 20$ & $\begin{array}{l}\text { Orientation and referral of people with malformations in the lip and roof of the } \\
\text { mouth (hare lip, cleft palate, cleft lip). }\end{array}$ & 0,53 & 0,5 \\
\hline E21 & Guidance on changes in food taste/palladate & 0,68 & 0,59 \\
\hline E22 & Guidance for people with bruxism & 0,70 & 0,75 \\
\hline E23 & Guidance on eating disorders/eating problems & 0,55 & 0,42 \\
\hline E24 & Guidance on fluorosis-caused issues & 0,65 & 0,71 \\
\hline E25 & Oral health guidance for caregivers of bedridden or disabled patients & 0,51 & 0,38 \\
\hline E26 & Oral Health Care and Guidance for People with Hypertension and/or Diabetes & 0,60 & 0,63 \\
\hline \multicolumn{4}{|c|}{ Comprehensiveness - Services Provided } \\
\hline F1 & Mouth examination / teeth examination / dental examination & 0,39 & 0,37 \\
\hline $\mathrm{F} 2$ & $\begin{array}{l}\text { Guidance on habits that can damage mouth and teeth (nail biting, cheek biting, } \\
\text { instance) }\end{array}$ & 0,58 & 0,37 \\
\hline F3 & Guidance on what to do to prevent oral cancer, & 0,59 & 0,46 \\
\hline $\mathrm{F} 4$ & Treatment and guidance on tooth wear & 0,54 & 0,48 \\
\hline F5 & Guidance on medications that interfere with the mouth & 0,56 & 0,42 \\
\hline F6 & Guidelines on how to perform oral hygiene (brushing/flossing) & 0,42 & 0,49 \\
\hline F7 & $\begin{array}{l}\text { Health education activities at the health facility or in the community (groups, } \\
\text { workshops, lectures) }\end{array}$ & - & $0,12^{\star}$ \\
\hline F8 & Guidance on changes that occur in the mouth with aging & 0,56 & 0,45 \\
\hline F9 & Guidelines on the water you drink & - & $0,24^{*}$ \\
\hline
\end{tabular}

^Items removed from the final instrument.

Source: Elaborated by the authors.

The first-contact access attribute was captured by factors 5 and 9 . The continuity attribute had its items kept in factor 4. Family orientation was captured by factor 3, which, in turn, kept items of Community Orientation. The interrelation of items of different attributes kept by common factors indicates that the complex dynamic nature of PHC services is represented by 
Table 4. Factorial loadings for factor validity and item-total correlation of attributes Family Orientation, Community Orientation and Cultural Competence.

\begin{tabular}{|c|c|c|c|}
\hline \multicolumn{2}{|r|}{ Attributes of Primary Health Care } & $\begin{array}{l}\text { Item-total } \\
\text { correlation }\end{array}$ & $\begin{array}{l}\text { Factorial } \\
\text { Loading }\end{array}$ \\
\hline \multicolumn{4}{|c|}{ Family Orientation } \\
\hline G1 & $\begin{array}{l}\text { You ask your patients about their ideas and opinions when planning treatment } \\
\text { and care for them or for a family member. }\end{array}$ & 0,48 & 0,41 \\
\hline G2 & $\begin{array}{l}\text { You ask about common ailments or issues that can occur in your patients' } \\
\text { families (mouth cancer, diabetes, high blood pressure, smoking, alcoholism?). }\end{array}$ & 0,43 & 0,44 \\
\hline G3 & $\begin{array}{l}\text { Are you willing and capable of seeing your patients' family members to discuss } \\
\text { a health problem? }\end{array}$ & 0,44 & 0,40 \\
\hline G4 & Do you use genograms and/or other instruments to evaluate family functioning? & - & $0,28^{\star}$ \\
\hline G5 & Do you have discussions about familiar risk factors of your patients? Ex: Genetic & - & $0,61^{\star}$ \\
\hline G6 & Do you discuss social risk factors with your patients, e.g. loss of employment? & 0,42 & 0,67 \\
\hline G7 & $\begin{array}{l}\text { Do you discuss the living conditions with your patients, e.g. a refrigerator in } \\
\text { operating conditions? }\end{array}$ & - & $0,59^{*}$ \\
\hline \multicolumn{4}{|c|}{ Community Orientation } \\
\hline H1 & Do you make home visits? & 0,49 & 0,32 \\
\hline $\mathrm{H} 2$ & $\begin{array}{l}\text { Do you believe that your health service has proper knowledge on health issues } \\
\text { of its community? }\end{array}$ & 0,51 & 0,33 \\
\hline H3 & $\begin{array}{l}\text { Does your health service community take into account opinions and ideas on } \\
\text { how to improve health services? }\end{array}$ & 0,51 & 0,37 \\
\hline $\mathrm{H} 4$ & $\begin{array}{l}\text { Can your health service adapt oral health services or programs to address } \\
\text { specific community-related health issues? }\end{array}$ & - & $0,32^{*}$ \\
\hline H5 & Patient surveys & 0,61 & 0,36 \\
\hline H6 & Community surveys & 0,68 & 0,38 \\
\hline H7 & "Feedback" from community organizations or health management boards & 0,67 & 0,50 \\
\hline $\mathrm{H} 8$ & "Feedback" from the healthcare team & 0,64 & 0,46 \\
\hline H9 & Systematic evaluations of programs and services provided & 0,44 & 0,41 \\
\hline H10 & $\begin{array}{l}\text { Presence of users in the Local Health Council (Management Council or Users } \\
\text { Council)? }\end{array}$ & 0,54 & 0,46 \\
\hline H12 & $\begin{array}{l}\text { An intersectional cooperation network with state and local agencies involved in } \\
\text { culturally diverse groups }\end{array}$ & 0,53 & 0,49 \\
\hline H13 & Associations with religious services/organizations & 0,53 & 0,52 \\
\hline H14 & Involvement with the associations/community leaders of the residents & 0,50 & 0,54 \\
\hline H15 & $\begin{array}{l}\text { Community workers or members of the managing council/district health } \\
\text { council }\end{array}$ & 0,44 & 0,37 \\
\hline \multicolumn{4}{|c|}{ Cultural Competence } \\
\hline I1 & $\begin{array}{l}\text { If necessary, do you take into account family beliefs on health care or the use of } \\
\text { traditional/popular medications, such as herbs/home medicine? }\end{array}$ & 0,11 & 0,32 \\
\hline I2 & $\begin{array}{l}\text { If necessary, do you consider the request from a family to use complementary } \\
\text { treatments such as homeopathy or acupuncture? }\end{array}$ & - & $0,32^{*}$ \\
\hline I3 & Staff training by external trainers & 0,58 & 0,68 \\
\hline I4 & Service training provided by the team itself & 0,71 & 0,79 \\
\hline I5 & $\begin{array}{l}\text { Use of culturally sensitive materials/pamphlets (posters, appropriate language, } \\
\text { religious customs) }\end{array}$ & 0,61 & 0,67 \\
\hline 16 & Team reflecting the cultural diversity of its population & 0,74 & 0,77 \\
\hline I7 & Service planning that reflects cultural diversity & 0,77 & 0,79 \\
\hline
\end{tabular}

Source: Elaborated by the authors.

the instrument, since, according to the concept of PHC, the attributes can be didactically divided, but are closely related in the practice of services ${ }^{16}$.
The instrument PCATool Brazil Oral Health Professional comprised 98 items. After an exploratory analysis, 13 of these items were excluded 
Table 5. Reliability measures for the seven attributes of PCATool Brasil SB - Professional Version.

\begin{tabular}{lcccrc}
\hline Attributes of Primary Oral Health Care & $\begin{array}{c}\text { Primary } \\
\text { Health Care } \\
\text { Scores }\end{array}$ & $\begin{array}{c}\text { Standard } \\
\text { deviation }\end{array}$ & $\begin{array}{c}\text { Cronbach's } \\
\text { Alpha }\end{array}$ & $\begin{array}{c}\text { Success } \\
\text { rate of the } \\
\text { scale (\%) }\end{array}$ & $\begin{array}{c}\text { P\#-value } \\
\text { for } \\
\text { Test-Retest }\end{array}$ \\
\hline First Contact - Accessibility & 4,4 & 1,46 & 0,55 & $88 \%$ & 0,18 \\
Continuity & 6,7 & 1,23 & 0,74 & $96 \%$ & 0,39 \\
Coordination of Care & 7,6 & 1,57 & 0,55 & $93 \%$ & 0,38 \\
Coordination - Information System & 7,7 & 1,57 & 0,21 & $21 \%$ & 0,91 \\
Comprehensiveness - Services Available & 8,9 & 1,12 & 0,91 & $100 \%$ & $<0,001$ \\
Comprehensiveness - Services Provided & 9,2 & 1,07 & 0,80 & $100 \%$ & 0,32 \\
Family Orientation & 7,5 & 1,93 & 0,66 & $94 \%$ & 0,65 \\
Community Orientation & 4,8 & 2,20 & 0,87 & $100 \%$ & 0,39 \\
Cultural Competence & 5,0 & 2,53 & 0,81 & $90 \%$ & 0,18 \\
\hline
\end{tabular}

*The scores assume values between 0-10. \#Associated with Wilcoxon signed-rank test.

Source: Elaborated by the authors.

for not presenting sufficient factor loading or because they assessed the same domain. The items suggested for evaluating the information system did not have sufficient factor loadings. We may speculate that this is a limitation related to the precariousness of information systems in Brazil, and also due to the fact that the national e-SUS Basic Attention system was only implemented in 2016. Nevertheless, due to its relevance in terms of planning, organization and evaluation of services $^{27}$, and to establish a comparison with other PCATool versions validated in Brazil, the authors decided to maintain it in the final version of the instrument.

The excluded access items are related to the provision of $\mathrm{OH}$ services in $\mathrm{PHC}$ on weekends or after 8 p.m. This practice is not common in the country and no reports were found in other studies regarding the availability of dental care in PHC after 8 p.m. The removed Care Coordination items are related to the delivery of exams in PHC and the provision of different specialized consultation services. Nonetheless, the Oral Health Team does not have the habit to request laboratory tests for PHC patients and more complex situations are referred to reference services, which are still insufficient in the country, not allowing the choice between different services ${ }^{28}$.

For the comprehensiveness attribute, the items related to the use of fluoride "Application of fluoride on teeth and guidance for its use" and fluorosis-related orientation "Guidance on excess fluoride on teeth/fluorosis" were also excluded from the final instrument. It may be pondered that this practice is not part of the routine of the professional who, given the high demand repressed, has its focus on recovery actions such as fillings and exodontia or pain relief measures. In addition, this study was conducted in urban areas with access to running water, which restricts the recommendations for fluoride use. Another important aspect is that access to fluoridated toothpaste is widespread in the country. On the other hand, identifying and monitoring the occurrence, distribution and aggravation of fluorosis is an epidemiological surveillance action, which is part of the tasks of PHC oral health teams and, still, they were not perceived by dentists as available services.

Regarding family orientation, the excluded items are related to the use of genograms and risk factor analysis. The use of genograms is an uncommon practice in PHC by oral health teams ${ }^{29}$. The items regarding the discussion of family risk factors, social risk factors and living conditions were represented by three different questions. According to the authors, all of them explain the same evaluative dimension and, therefore, the option made was to maintain the highest loading in terms of discussions on social risk factors.

The results of the reliability analysis point out the consistency of all attributes, except for Care Coordination - Information Systems, which was assessed as insufficient. Nevertheless, the option was to maintain the items because they represent Starfield's concept of $\mathrm{PHC}^{1}$ and to maintain comparability with other PCATool versions validated in Brazil. The results of the scale success ratio show that each item is allocated in its conceptual attribute, because they are more strongly 
related to the items of its source component than to those of the other attributes, therefore consubstantiating the reliability of the instrument.

The use of service valuation instruments is an important resource, which is nowadays used in many countries. To avoid measurement bias in these instruments, it is extremely important that the process of factor validation is performed for each one. Stein ${ }^{30}$ points out that it is also necessary to take into account the concepts established in the literature, as well as cultural factors, particularly in epidemiological and clinical studies, and methodological rigor in the execution of the process.

The comparison between the test and the retest identified the stability of the scale over time. The comprehensiveness attribute - Services Available - showed low agreement on retesting and it is possible the rotativity of professionals in services may have influenced these results. Another possible limitation of the instrument is its large number of items (85), which may result in the interviewee not having the same willingness to answer all items. The possibility of having a reduced version of this instrument is suggested, which was already developed for another version of PCATool Brazil, one that presented reliable psychometric properties for the instrument ${ }^{31}$.

PCATool Brazil Oral Health - Professional captured the main attributes of PHC and generally presented acceptable measures of validity and reliability. The use of scale may account for a valuable instrument for evaluative research efforts and for the organization of oral health services in PHC in the different management areas, since it allows the analysis of the effect of interventions, policies and programs. According to a survey carried out by the authors, this is the only PCATool Brazil Oral Health - Professional described in the international literature with the derived attribute Cultural Competence validated. Moreover, the instrument has essential features for comparability, since it was designed as a mirror version of PCATool Brazil Oral Health - Professional for doctors/nurses - and is also used in other countries ${ }^{32-35}$.

\section{Collaborations}

OP D'Avila, FN Hugo and E Harzheim contributed to the design, execution, development and final review of the study. L Hauser, LFS Pinto were responsible for the execution and review of the data analysis as well as the final review of the results. ED Castilhos contributes to the final revision of the article, textual adjustments and improvement of the data discussion. 


\section{References}

1. Starfield B, Shi L, Macinko J. Contribution of Primary Care to Health Systems and Health. Milbank Q 2005; 83(3):457-502.

2. Starfield B. Atenção Primária: equilíbrio entre necessidades de saúde, serviços e tecnologia. Brasília: Unesco; 2002.

3. Starfield B, Shi L. Policy relevant determinants of health: an international perspective. Health Policy 2002; 60(3):201-218.

4. Macinko J, Starfield B, Shi L. The contribution of primary care systems to health outcomes within Organization for Economic Cooperation and Development (OECD) countries, 1970-1998. Health Serv Res 2003; 38(3):831-865.

5. Brasil. Ministério da Saúde (MS) [Internet]. Brasília: MS; 2020 [acessado 2020 jun 10]. Disponível em: https://egestorab.saude.gov.br/paginas/acessoPublico/relatorios/relatoriosPublicos.

6. Pimentel FC, Albuquerque PC, Martelli PJL, Souza WV, Acioli RML. Caracterização do processo de trabalho das equipes de saúde bucal em municípios de Pernambuco, Brasil, segundo porte populacional: da articulação comunitária à organização do atendimento clínico. Cad Saude Publica 2012; 28(Sup. 1):s146-s157.

7. Campbell S, Roland M, Buetow S. Defining quality of care. Soc Sci Med 2000; 51:1611-1625.

8. Haggerty J, Burge F, Levesque JF, Gass D, Pineault R, Beaulieu MD, Santor D. Operational definitions of attributes of primary health care: consensus among Canadian experts. Ann Fam Med 2007; 5(4):336-344.

9. Shi L, Starfield B, Xu J. Validating the adult Primary Care Assessment Tool. J Fam Pract 2001; 50(2):161175.

10. Cassady CE, Starfield B, Hurtado MP, Berk RA, Nanda JP, Friedenberg LA. Measuring consumer experiences with primary care. Pediatrics 2000; 105(4 Pt 2):9981003.

11. Shi L, Starfield B, Politzer R, Regan J. Primary care, self-rated health, and reductions in social disparities in health. Health Serv Res 2002; 37(3):529-550.

12. Harzheim E, Duncan BB Stein AT, Cunha CR, Goncalves MR, Trindade TG, MMC Oliveira, MEB Pinto. Quality and effectiveness of different approaches to primary care delivery in Brazil. BMC Health Serv Res 2006; 6:156.

13. Harzheim E, Oliveira MMC, Agostinho MR, Hauser L, Stein AT, Gonçalves MR, Trindade TG, Berra S, Duncan BB, Starfield B. Validação do instrumento de avaliação da atenção primária à saúde: PCATool-Brasil adultos. Rev Bras Med Fam Comunidade 2014; 8(29):274-284

14. Harzheim E, Starfield B, Rajmil L, Álvarez-Dardet C, Stein AT. Consistência interna e confiabilidade da versão em português do Instrumento de Avaliação da Atenção Primária (PCATool-Brasil) para serviços de saúde infantil. Cad Saude Publica 2006; 22(8):16491659.

15. Castro RCL, Knauth DR, Harzheim E, Hauser L, Duncan BB. Avaliação da qualidade da atenção primária pelos profissionais de saúde: comparação entre diferentes tipos de serviços. Cad Saude Publica 2012; 28(9):1772-1784.
16. Hauser L, Castro RCL, Vigo A, Trindade TG, Gonçalves MR, Stein AT, Duncan BB, Harzheim E. Tradução, adaptação, validade e medidas de fidedignidade do Instrumento de avaliação da Atenção Primária à Saúde (PCATool) no Brasil: versão profissionais de saúde. Rev Bras Med Fam Comunidade 2013; 8(29):244-255.

17. Cardozo DD. Validação e aplicação PCATool-SB para avaliação da qualidade da Atenção Primária à Saúde Bucal - versão usuários [tese]. Porto Alegre: Universidade Federal do Rio Grande do Sul; 2015.

18. Fracolli LA, Gomes MFP, Nabão FRZ, Santos MS, Cappellini VK, Almeida ACC. Instrumentos de avaliação da Atenção Primária à Saúde: revisão de literatura e metassíntese. Cien Saude Colet 2014; 19(12):4851-4860.

19. Agência Brasil. Ministério da Saúde e IBGE coletarão dados sobre população infantil [Internet] [acessado $2019 \mathrm{dez}$ 13]. Disponível em: http://agenciabrasil.ebc.com.br/saude/noticia/2019-12/ministerio-da-saude-e-ibge-coletarao-dados-sobre-populacao-infantil.

20. Harzheim E, D'Avila OP, Ribeiro DC, Ramos LG, Silva LE, Santos CMJ, Costa LGM, Cunha CRH, Pedebos LA. Novo financiamento para uma nova Atenção Primária à Saúde no Brasil. Cien Saude Colet 2020; 25(4):1361-1374.

21. Brasil. Ministério da Saúde (MS). Secretaria de Atenção Primária à Saúde. Departamento de Saúde da Família. Manual do Instrumento de Avaliação da Atenção Primária à Saúde: PCATool-Brasil. Brasília: MS; 2020.

22. Brasil. Ministério da Saúde (MS). Programa Nacional de Melhoria do Acesso e da Qualidade da Atenção Básica (PMAQ): manual instrutivo. Brasília: MS; 2012

23. D'Avila OP, Pinto LFS, Hauser L, Gonçalves MR, Harzheim E. O uso do Primary Care Assessment Tool (PCAT): uma revisão integrativa e proposta de atualização. Cien Saude Colet 2017; 22(3):855-865.

24. Fontanive LT. Adaptação do instrumento Primary Care Assessment Tool - Brasil versão usuários dirigido à Saúde Bucal [dissertação]. Porto Alegre: Universidade Federal do Rio Grande do Sul; 2011.

25. Hauser L. Aprimoramento do Instrumento de Avaliação da Atenção Primária à Saúde (PCATool-Brasil) [tese]. Porto Alegre: Universidade Federal do Rio Grande do Sul; 2016.

26. Stewart DW. The Application and Misapplication of Factor Analysis in Marketing Research. J Marketing Res 1981; 18:51-62.

27. Carreno I, Moreschi C, Marina B, Hendges DJB, Rempel C, Oliveira MMC. Análise da utilização das informações do Sistema de Informação de Atenção Básica (SIAB): uma revisão integrativa. Cien Saude Colet 2015; 20(3):947-956.

28. Pimentel FC, Martelli PJL, Araújo Junior JLA, Acioli RML, Macedo CLV. Análise da atenção à saúde bucal na Estratégia de Saúde da Família do Distrito Sanitário VI, Recife (PE). Cien Saude Colet 2010; 15(4):2189-2196.

29. Reis CMR. Describing the primary care Actions of oral health teams in Brazil. Int J Environ Res Public Health 2015; 12(1):667-678. 
30. Stein AT. A avaliação dos serviços de saúde deve ser realizada com instrumentos validados. Epidemiol Serv Saude 2013; 22(1):179-181.

31. Oliveira MMC, Harzheim E, Riboldi J, Duncan BB. PCATool-ADULTO-BRASIL: uma versão reduzida. Rev Bras Med Fam Comunidade 2013; 8(29):256-263.

32. Berterretche R, Sollazzo A. El abordaje de la Atención Primária de Salud, modelos organizativos y prácticas: caso de un centro de salud público urbano de Montevideo, Uruguay 2011. Saude Debate 2012; 36(94):461472.

33. Berra S, Hauser L, Audisio Y, Mántaras J, Nicora V, Oliveira MMC, Starfield B, Harzheim E. Validez y fiabilidad de la versión argentina del PCAT-AE para evaluar la atención primaria de salud. Rev Panam Salud Publica 2013; 33(1):30-39.

34. Lee JH. Development of the Korean primary care assessment tool - measuring user experience: tests of data quality and measurement performance. Int $J$ Qual Health Care 2009; 21(2):103-111.

35. Yang H, Shi L, Lebrun LA, Zhou X, Liu J, Wang H. Development of the Chinese primary care assessment tool: data quality and measurement properties. Int $J$ Qual Health Care 2013; 25(1):92-105.

Article submitted 02/07/2020

Approved 27/09/2020

Final version submitted 29/09/2020

Chief Editors: Maria Cecília de Souza Minayo, Romeu Gomes, Antônio Augusto Moura da Silva 